\title{
Social and Philosophical Analysis of Power as a Social Phenomenon
}

\author{
Alexander Petrovich Bandurin ${ }^{1}$
}

Elena Emirbekovna Emirbekova²

\section{Andrei Yurievich Goloborod'ko³}

\author{
Igor Alexandrovich Guskov ${ }^{4}$
}

Zaur Askerbievich Zhapuev ${ }^{5}$

\author{
${ }^{1}$ Southern Federal University, Rostov-on-Don, Russian Federation; Email: infoippk@sfedu.ru \\ 2 The branch of the Southern Federal University in Makhachkala, Republic of Dagestan, Russian Federation \\ ${ }^{3}$ Chekhov Taganrog Institute of the Branch of the Rostov State Economic University, Taganrog, Russian Federation \\ ${ }^{4}$ Southern Federal University, Rostov-on-Don, Russian Federation \\ ${ }^{5}$ Kabardino-Balkarian State University, Nalchik, Russian Federation
}

Doi:10.5901/mjss.2015.v6n4s4p82

\begin{abstract}
The article discusses power as a social phenomenon in the social and philosophical context. The interpretations of the concept of "power" in different historical periods are studied, the specificity of interpretations of power within the social and philosophical concepts is revealed. Power as a social phenomenon has such characteristic features as relationship "domination-obedience", which acting as one of the mechanisms regulating the behavior, acquired during the sociogenesis, operationalizes the positive and negative sanctions of power. Study of power as a social phenomenon in the submitted article includes two main aspects: an analysis of approaches to the interpretation of the concept of "power" and an analysis of the paradigms, within which the study of power was performed actually.
\end{abstract}

Keywords: power, social phenomenon, dominance, obedience

\section{Introduction}

The social and philosophical analysis of power as a social phenomenon is relevant because the phenomenon of power has been in the focus of philosophers virtually from the very beginning of its formation. This is explained in particular by the fact that power is inherent to all stages of development of a society, because in a society people always have different interests at the individual and group levels, which cause social tensions and cannot be settled by any means except by an order "from above," i.e. by those who have the opportunity to order thus imposing their will. Power also is related to authority, and one of its correlates is respect, which provides power with ethical value. On the other hand, power also has a certain demonic appeal. That is why in the perception of Orthodox Christians, power is sinful, and the one who has power is a sinner. l.e. actually, there are the two components of power: the definition of it as a social phenomenon, as such, and the direction of its study.

Thus, the study of power as a social phenomenon will include two aspects: an analysis of approaches to the interpretation of the concept of "power" and an analysis of the paradigms, within which the study of power was performed.

\section{Definition of the Concept of "Power"}

A particular problem in the definition of the concept of "power" is its in-depth, subconscious, and emotional-volitional basic principles. They have been traditionally studied in the mainstream of social sciences (philosophy, sociology, psychology), as well as in the literary and political creative work of the best minds of humanity. Indeed, the manifestation of power, leadership is natural for humans; it is deeply embedded in biological, natural, and socially conditioned principles of their intellectual and emotional-volitional life. No less important, and equally complex biosocial nature is attributed to the other, mirror-side of power-obedience, voluntary or forced consent to perceive the impacts of power and to obey them. Command and obedience-these are two equally universal principles of power. They are inseparable and interact 
as two types of personalities-the one prone to dominate ("leader") and the one obedient, accepting the power ("led"). Both types are socially needed. They are reproduced in the form of large social structures and relationships between them-the state and the society, the government and the population, etc. Civilized humanity is focused on the coordination of these relationships, on turning them into organized and, if possible, conflict-free ones (Shchekin, 1996).

Starting with ancient philosophers, there have been attempts to define this concept, as well as to classify power as a social phenomenon. One of the first classifications of power was suggested by Aristotle, who, depending on whether power is used for the benefit of all or a certain part of the society, singled out the right and wrong forms of governing. Polybius, probably as a consequence of observation, taught that any government (monarchical, aristocratic, democratic) will inevitably degenerate due to congenital tendency of people to abuse power. A similar approach was professed by Cicero who distinguished three main types of power: the perfect (perfecta), best (optima), and tolerable (tolerabilis) ones. At the same time, both Polybius and Cicero considered a mixed form of government as a panacea for the decline of power, since in this case power is evenly distributed between the main elements of social organization. Thus, in the Greco-Roman philosophy, there were two basic concepts of power: power as domination of personality over itself and power as the basis of the structure of state. The first interpretation was typical of all ancient philosophers as a fundamental principle of culture. It was represented in the most detailed form by Plato, Marcus Aurelius, and Seneca. "Manifest the properties that depend entirely on you: sincerity, seriousness, endurance, disregard for pleasure, contentment with your fate, scarcity of needs, benevolence, freedom, moderation, no idle talk and arrogance. Do you know from how many sides of yours you can still approve yourself, in respect of which you cannot refer to natural inability ...?" (Marcus Aurelius, 1991). The second one was thoroughly developed by Plato and Aristotle. However, the ability to ruling over a polis, a state was deduced by philosophers from the ability to control oneself, because it is the ability to control oneself that is an indicator of the individual's ability to govern others.

Christianity made the theocratic understanding of power the dominant concept. This understanding of power was theoretically developed in the writings of Tertullian and Augustine of Hippo. They also gave justification of the power on Earth through the regulated and justified power vertical stretching from God to his governor and intermediaries on Earth. At the turn of the Middle Ages and Modern Times, N. Machiavelli desacralized the recepts of power by conceptualizing the idea of a state as the only decent and competent source and medium of power, singling out policy as an autonomous sphere, and separating it from morality and religion.

In the philosophy of the Early Modern History, the emphasis moves to understanding power as one of the consequences of people's sovereignty. However, the state remained the medium of power, being an independent structure, to which sovereignty was delegated. The main form of exercising power was violence, to perpetrate which the state had the full right, as the spokesman of the popular will. However, subjects also remained eligible for violence against the state in the form of rebellion. This position is most clearly seen in the works of T. Hobbes (Hobbes, 1936) and J. Locke (Locke, 1985). At the same time, the state was deemed to have the focus of power. Later on, this position was developed by I. Kant in his theory of the rule-of-law state, in which the state power, being a set of ruling structures, is a rationally determined resource of management, and by $\mathrm{H}$. Hegel, in whose theory the state has a monopoly of power and, as a consequence, freedom of choice, including the use of force. M. Weber defined power as the expression of one's will and overcoming "the will of others with one's will" (Weber, 1990). R. Dahl had a close understanding of this position. He believed that power is the ability to force others to do what they would not do in their own volition (Dahl, 2012). $\mathrm{H}$. Lasswell and A. Kaplan (Lasswell and Kaplan, 1950) considered that power is primarily the participation in and influence on decision-making, while T. Parsons in determining power shifted the focus to the ability to manage resources, by means of which the set goals can be achieved (Parsons, 1994). R. Aron had a position close to Parsons'-he understood power as the potential of a person or a group to establish relationships with those whose opinion coincides with their own desires (Aron, 1992). B. Russell defined power as the achievement of the initially desired results (Russell, 2001). Herewith, he did not accept the position of Hobbes on the issue: "The curious result of his selfish ethics is the assertion that the resistance to the government is justified only in the case of self-defense, while resistance to protect another person is always a crime. There is another, quite logical exception: a person has no obligations to the governor, who has no power to protect him. It justified the submission to Cromwell at the time when Charles II was in exile" (Russell, 1991).

Modern science recognizes the following classification systems of power: 1) by types (political, economic, government, family-based); 2) by forms (dominance, leadership, management, organization, control); 3) by methods of exercising power (authority, law, violence).

However, most scientists believe that power and the desire for power or obedience, depending on the natural inclination of the person, are inherent in human nature, as everybody, in one form or another, tends to either govern or obey. And often thoughts about power shift to the field of "how to limit the power?" That is, if we systematize the power definitions by the manifestations aspects (social, political, psychological, epistemological), its features as of a social 
phenomenon appear more clearly. For example, in the social aspect, power appears as dominance in relationships, because power has the ability to exercise freedom of action based on one's objectives without taking into account the desires of second parties. The political aspect of power involves the use of power as a way to exercise one's influence, subordination, coercion based on the actual balance of forces. The psychological aspect of power, above all, the leadership relations in interpersonal interaction, in the process of which the leader (who has power) and the led (performer) are determined. In the epistemological aspect, power is a purposeful way of combining the dual nature of power, which includes knowledge as such and will: knowledge actualizes conscious calculation of actions and their consequences in the context of specific circumstances; and will subjects available resources to achieving the set goal.

Separately and in a certain interweaving, various aspects of power are represented in the concepts of power, which will be considered successively later on, as they present the power phenomenon in a more multifaceted manner, reflecting the evolution of views on this scientific issue.

Classical philosophical concepts of power. They emphasize the ability of individuals to exercise their will, both subjective and collective. That is, in the classic concepts, power is considered as part of the "master - slave" dichotomy, which originates from the writings of Plato and Aristotle. Further development of this approach was proceeded in the following dichotomies: "god - believers' (sacred representations of the Middle Ages); "sire - lieges" (Machiavelli, 1982); "ruling class - proletariat" (Marx and Engels, 1955). Also, within the framework of classical philosophical concepts, the following classifications were suggested: power (legal/charismatic/traditional); views (political, economic, government, family); forms (dominance, leadership management, organization, control); methods (authority, law, violence).

For a sufficiently long time, the social contract theories dominated, according to which power was understood as a derivative of the law. These beliefs were professed by T. Hobbes, J. Locke, B. Spinoza, J.-J. Rousseau, and I. Kant. M. Weber clearly defined power as the primary phenomenon, from which policy derives: "Policy for us means the hope to participate in power or influence its distribution both between states and within one state between groups of people" (Weber, 1990). Following M. Weber and agreeing with him concerning the primacy of power, Freund, however, believed that power and policy are equally autonomous and relate to a specific historical situation. That is the essence of power is a competitive political activity, and its universal principle (command/obedience) creates a universal category, which, in the views of Freund, holds the position correlating with a particular level of policy as a specific activity (Freund, 1992). However, Freund did not associate power in its first principle with other social phenomena, focusing on the relations of command and obedience attributed only to power. Just because of this specificity of power relations, he concluded three basic political grounds: 1) general policy functions constituting social relations; 2) a system of relations "friends enemies"; 3) existence in the society of two social sectors (private and public). Based on this, he concludes that political principle is the quintessence of a social start, setting the tone of any society, because no society is or can be apolitical.

The behavioral concepts of power base on the ideas that were formulated in the early twentieth century by scientists of the University of Chicago, as a result of studying the behavior of people in the political sphere based on the behavioral psychological direction. Behaviorists studying power explain its presence in the society as a phenomenon, typical, in their opinion, only of the human nature's strive for power and will, and consider political relations within the framework of the market model of relations as a kind of power market, where power entities enter into "deals" to obtain the power and the privileges available due to the power (similar to the socioeconomic market as a regulator of economic relations). The guarantee of the agreement implementation by the parties lies in two elements: goodwill and external force that is outside (above) the deal and therefore able to control its progress.

In the non-classical philosophical concepts of the "governor - slave" opposition, the essence of power was actually revised and a new understanding of it as an ideological phenomenon, fully controlled by mind, was suggested.

In particular, the irrationalism school of European philosophy formulated a fundamentally different idea of power. Its forerunner was A. Schopenhauer who put forward the concept of "the will of the world" as the driving force of all life and development. Next, starting from this idea, Nietzsche proposed to the scientific community the theory of the existence of a certain impersonal force, which he called "the will to power", and which was, in his view, the foundation of existence and came as the universal principle: "Who cannot command to himself shall obey" (Nietzsche, 1990). Nietzsche's "will to power" acts as an instrument of personality, applied by it to implement the desired. That is, power, as understood by Nietzsche, is identical to life. And while classical philosophy interprets power as an effect of social action, here it acts as a universal form of expression of the life force, because existence and development appear as certain results of the power struggle.

These ideas of irrationalism were adopted by French philosophy, from structuralism to the "New Left." Thus, Foucault saw the structural organization of power as an originally decentered establishment, justifying the absence of the sovereign (hierarchically privileged unit) with the specificity that consisted in ubiquity. It is the omnipresence of power that sets a new perspective of its perception as a self-organizing forceful process, taking place between the conflicting 
parties devoid of theological dimension. At the same time, the nature of power, according to Foucault, is in the unconscious, crystallizing on the surface into social hegemony and state institutions and finding its identity in the sense of intentions of the social life, especially at the micro level (localization of sex, classification of pleasure). Bart, in the context of Nietzsche's intuition about the rootedness of power, figures power and power relations out of the language, transferring the language from the category of a neutral means of communication to the primary level of coercion and "legitimizing" the established order of dominant hierarchical relations on the linguistic level. Even more radical interpretations of power as a byproduct of the "production of desire" can be found in the writings of Deleuze and Guattari. Herewith, the former believes that "not only prisoners are treated like children, but also children are treated like prisoners. Children are victims of infantilization and stultification that are not inherent in them. And in this sense, it is quite true that schools are prisons to a certain extent, and plants are almost prisons" (Deleuze, 2010). Thus, a common feature in the non-classical concepts of power are the attempts to classify it and highlight its forms and methods, which indicates the transition from the definition of power to its systematization.

In the middle of the twentieth century, in the course of development of linguistic philosophy, there was comprehension of the language having reigning aspects and, therefore, acting as a subjectless carrier of social power. This trend has led to the interpretation of the world as a text, the space as a space of characters, and a character as a marking, explaining, inducing element of being, dominating in the social space (U. Eco 2006). As in the twentieth century, the masses began to play a larger role in the social life, the phenomenon of masses occurred in the philosophical scientific horizon, and J. Ortega y Gasset registered the emergence of a new non-local form of power, which despite being spread in mass affects the life of the entire society (Ortega y Gasset, 1991). M. Foucault included in his works devoted to the analysis of power as part of his concept "knowledge - power" its features, such as the discursive and dispersed nature, semiotic completeness, mass involvement, and conducted a study of the non-discursive aspects of the power practices through the introduction of the principle of corporeality and addition of the concept of optical organization of spaces of power exercising. In the course of studying power in the "knowledge - power" system, Foucault concluded that power through the organization of social space produces subjectivity, acting as the "creator" of a subject and sociality.

Thus, in contrast to the classical essential features of power (prohibition and violence), power has other essential properties-productivity and organization. In addition, Foucault discovered a new level of relations of power forces-the "microphysical" level, which he interpreted as the basic one due to the fact that exactly at this level, the discursive and non-discursive practices' elements intertwine, forming the specificity of the lifeworld and as a result, the outlook of a person, as well. To a large extent, based on the concept of M. Foucault, attempts were made to understand philosophically the everyday life, which allowed to analyze the origin, development, and functioning of power practices, determining the context of everyday social activities, i.e. how exactly the formation of subjectivity and social organization by the force of power takes place.

\section{Conclusions}

An analysis of the development of representations of power and conceptual approaches to the study of power as a social phenomenon in the social and philosophical scientific knowledge makes it possible to conclude that, despite their differences, the intrinsic bases of power have common typical features.

1. Power is based on the dichotomous understanding of the "domination - obedience" relationship, as manifestation of power always means imposing one's will on another's.

2. The "domination - obedience" relationship appears, along with rituals, customs, traditions, laws, as one of the mechanism of behavior regulation acquired in the sociogenesis.

3. The relationship "domination - obedience" operationalizes sanctions of power: positive (stimulating voluntary obedience) and negative (coercion).

4. The origins of the "domination - obedience" relationship reside in the objective heterogeneity of the society and, as a consequence, the hierarchical ranking of people within the society, giving the right to ones for more freedoms and rights.

5. The purpose of power is either unification or separation of individuals, groups, and masses. To achieve the goal of power, both direct and indirect methods of influence can be used.

\section{References}

Lasswell, H.D., \& Kaplan, A.K. (1950). Power and Society. New Haven: Yale University Press. 
Aron, R. (1992). Etapy razvitiia sotsiologicheskoi mysli [Stages of development of sociological thought] (P.S. Gurevich, Ed.). Moscow: Publishing group "Progress", "Politika" [in Russian].

Weber, M. (1990). Protestantskaia etika i dukh kapitalizma [The Protestant ethic and the spirit of capitalism]. Selected Works. Moscow: Progress [in Russian].

Hobbes, T. (1936). Leviafan ili materiia, forma i vlast' gosudarstva tserkovnogo i grazhdanskogo [Leviathan: or The Matter, Form, and Power of a Commonwealth, Ecclesiastical and Civil]. Moscow [in Russian].

Dahl, R. Poliarkhiia: uchastie i oppozitsiia [Polyarchy: Participation and Opposition]. Retrieved from Http://kant.narod.ru/dahl.htm [in Russian].

Deleuze, G. (1998). Logika smysla [The logic of sense] (J.I. Svirsky, Trans.). Moscow: Raritet; Yekaterinburg: Delovaia Kniga; Moscow: Akademitcheskii Proekt [in Russian].

Locke, J. (1985). Opyt o chelovecheskom razume [Essay Concerning Human Understanding] (Works in 3 vols, Vol. 1). Moscow: Mysl' [in Russian].

Machiavelli, N. (1982). Gosudar' [The emperor] (G. Murav'eva, Trans.). Original Issue: Machiavelli, N. Selected Works. Moscow: Khudozhestvennaia Literatura [in Russian].

Aurelius, M. (1991). Naedine s soboi. Razmyshleniia [Alone with myself. Reflections]. Rostov-on-Don: Publishing House of RSU [in Russian].

Marx, K., \& Engels, F. (1995). Nemetskaia ideologiia [The German ideology] (2nd ed., Vol. 3). Moscow: Politizdat.[in Russian].

Nietzsche, F. (1990). Tak govoril Zaratustra [Thus spoke Zarathustra]. Collection of works in 2 volumes (Vol. 2). Moscow: Mysl' [in Russian].

Ortega y Gasset, J. (1991). Uglublenie v sebia i obrashchennost' vovne [The deepening of an outward and treatment]. Filosofskie Nauki - Philosophic Sciences, 5 [in Russian].

Parsons, T. (1994) Sistema koordinat deistviia i obshchaia teoriia sistem deistviia: kul'tura, lichnost' i mesto sotsial'nykh [The coordinate system of action and general theory of action systems: culture, personality, and place of social systems]. Amerikanskaia sotsiologicheskaia mysl': Teksty - American Sociological Thought: Texts (V.I. Dobrenkov, Ed.). Moscow: MSU Publishing House [in Russian].

Russell, B. (2001). Istoriia zapadnoi filosofii [History of western philosophy] (3 volumes, 3rd ed., Rev). (V. Tselischev, Ed.). Novosibirsk: Publishing House of NSU [in Russian].

Russell, B. (2001). Istoriia zapadnoi filosofii [History of western philosophy] (3 volumes, 3rd ed., Rev). (V. Tselischev, Ed.). Novosibirsk: Publishing House of NSU [in Russian].

Freund, J. (1992). Sushchnost' vlasti. Etapy razvitiia sotsiologicheskoi mysli [The essence of power. Stages of development of sociological thought] (Trans.). Moscow: Publishing group "Progress", "Politics" [in Russian].

Shchekin, G.V. (1996). Teoriia sotsial'nogo upravleniia: Monografiia [The theory of social control: Monograph]. Kiev: MAUP [in Russian].

Eco, U. (2006). Otsutstvuiushchaia struktura. Vvedenie v semiologiiu [Lacked structure. Introduction to semiology] (B. Reznik \& A. Pogoniailo, Trans.) St Petersburg: Simposium [in Russian]. 